\title{
Variability of precipitation in Poland under climate change
}

\author{
Małgorzata Szwed ${ }^{1}$ (D)
}

Received: 2 November 2016 / Accepted: 3 February 2018 / Published online: 26 February 2018

(C) The Author(s) 2018. This article is an open access publication

\begin{abstract}
The surface warming has been widespread over the entire globe. Central Europe, including Poland, is not an exception. Global temperature increases are accompanied by changes in other climatic variables. Climate change in Poland manifests itself also as change in annual sums of precipitation. They have been slightly growing but, what is more important, seasonal and monthly distributions of precipitation have been also changing. The most visible increases have been observed during colder half-year, especially in March. A decreasing contribution of summer precipitation total (June-August) to the annual total is observed. Climate projections for Poland predict further warming and continuation of already observed changes in the quantity of precipitation as well as its spatial and seasonal distribution.
\end{abstract}

\section{Introduction}

Warming of the global climate system is unequivocal, as evidenced by observations of increases in air temperatures at various spatial scales - local, national, regional, continental, hemispheric, and global (IPCC 2013). The surface warming has been widespread over the entire globe. Each of the 16 years of the twenty-first century, 2001-2016, belongs to a set of 17 globally warmest years on record (NOAA 2017). Global temperature changes are accompanied by changes in other climatic variables. Thus, precipitation totals have been changing. Precipitation has increased in the mid to high latitudes over the last century. An increase of 10-50\% has been observed over northern and western Europe (Watson et al. 1998). Central Europe, including Poland, is not an exception.

Annual sums of precipitation have been slightly changing in Poland. They have been slightly growing but, what is more important, seasonal and monthly distributions of precipitation have been also changing. Several authors have reported changes in the sum of precipitation in Poland in different timescale (annual, seasonal, and monthly) and changes in its distribution during a year. Some studies cover examination of precipitation in the period before the warming became global, while the others deal with the global warming period. For instance,

Małgorzata Szwed mszwed@man.poznan.pl

1 Institute for Agricultural and Forest Environment of Polish Academy of Sciences, Bukowska 19, 60-809 Poznań, Poland
Kożuchowski (2004) stated that a slight increase in precipitation totals can be observed, but it does not exceed the level of significance. Also, Wybig (2009) confirmed it claiming that precipitation in Poland did not change greatly in the second half of the twentieth century, and Żmudzka (2002) detected a not statistically significant increasing trend in annual totals. Next, Degirmendžić et al. (2004) noticed an increase in precipitation total in March and a decline of the summer precipitation share in annual totals in the periods 1951-2000. Then, Czarnecka and Nidzgorska-Lencewicz (2012) reported on a slight increasing tendency for precipitation totals in spring and autumn and decreasing trend in the share of summer precipitation in annual totals over a predominant area of Poland. It is impossible to refer here to all authors, but some of the research papers will be quoted in the Section 5 .

Researchers from neighboring countries are also interested in the issues of precipitation variability, but it seems that the vast majority of them discuss maximum, extreme, or intense/ heavy rainfall (Kyselý 2009; Hundecha and Bardossy 2005; Zolina et al. 2014; Rimkus et al. 2011). However, there are also some papers dealing with the variability of average precipitation coming mainly from Germany, but also from countries South and East from Poland.

The precipitation trend analysis for the periods 1951-2006 for Central Eastern Germany shows increasing precipitation in winter and decreasing precipitation in summer. Summer precipitation decrease is the most pronounced. The positive trends are spatially most homogenous in February, March, November, and December, whereas the most uniform negative trends have been observed from April to July and in 
October (Hänsel et al. 2007). Murawski et al. (2016) claim that changes in precipitation in Germany are season and even month specific. The variability of daily precipitation has changed in parallel with the mean behavior: those regions and seasons that show an increase in the mean show also an increase in standard deviation. Brienen et al. (2013) were very careful when formulating the conclusions. Authors noticed that tendencies in daily precipitation in Germany over the twentieth century are variable and climate change statements are very sensitive to the considered time period. However, several significant trends are observed in precipitation total in Germany. Significant trends are much more frequently observed for the winter season than for summer. In the second half of the twentieth century, the summer season is characterized by reduced total precipitation. Based on monthly precipitation totals from 487 gauging stations in Slovakia in the periods from 1981 to 2013, Zeleňáková et al. (2016) stated that precipitation trends show high variability, however, in majority of the area, increasing precipitation trends prevailed, and for July, there were significant for more than $50 \%$ of stations. Researches for Ukraine were done by Ivanov et al. (2009). It was stated that estimates of a trend in precipitation vary depending on a sampling period and may even change the sign. Authors suggest that changes in precipitation should be described as a long-term variability rather than a trend. Tripolskaja and Pirogovskaja (2013) reported that during the periods 1987-2007, in the studied territory of Lithuania (Vilnius), the precipitation totals slightly increased $(13 \mathrm{~mm})$ compared to the climate normal (1961-1990), while in Belarus (Minsk), the precipitation totals decreased by $109 \mathrm{~mm}$ compared to the climate normal; a greater decrease was observed in summer $(50 \mathrm{~mm})$.

The transitional, maritime-continental nature of the Polish climate is caused by the country's location in the area where continental and oceanic masses often collide, resulting in relatively large day-to-day and year-to-year variability in the weather patterns. The latitudinal belt system of hypsometry in Poland facilitates the free flow of air masses in the east-west parallel direction. The inflow of air masses from the West to Poland is most frequent (24\%) (Woś 1996). Thus, precipitation is the basic component of climate which is characterized by large temporal variability. What's more, for example, Brazdil and Kożuchowski (1986) claim that a general growing tendency of annual precipitation variability can be observed throughout the periods of 1881-1980.

Precipitation in Poland displays also a great spatial variety and dependence on hypsometry. On the map of annual precipitation totals, it is easy to see the pattern of their spatial distribution corresponding to the layout of main geographic regions. Thus, the lowest annual precipitation totals are characteristic for central lowland part of Poland (less than or about $600 \mathrm{~mm}$ ). Even small elevations receive markedly higher precipitation (average by about $60 \mathrm{~mm}$ per $100 \mathrm{~m}$ in height
(Brazdil and Kożuchowski 1986)). Then, precipitation is increasing to the north and south directions. In the northern direction, the absolute altitudes rise and lowlands convert into hilly Lake Districts/Pomerania and continue to descend to the Baltic. Similarly, precipitation reaches the highest values in the Lake District (mainly windy side of the slopes) and on the coast (700-750 mm), where the influence of the Baltic Sea on the increase of precipitation is noticeable. In the southern direction, the lowlands transform into the uplands, followed by foothills and higher mountains. According to this arrangement, annual precipitation totals are increasing to reach values up to $1600 \mathrm{~mm}$ in the highest parts of the Tatra Mountains.

Precipitation is the key element affecting water availability. In the present climate, many regions of Poland suffer frequent shortage of water, especially in the growing season. In the future, this shortage may become even more severe because climate projections for Poland predict further warming and further changes in the spatial and seasonal distribution and quantity of precipitation (Szwed et al. 2010). On the other hand, one should remember that the predicted future warming does not have to be tantamount to reduce the water availability in the region. In principle, even with decreasing sums of total precipitation, its seasonal distribution can be advantageous in the future. However, climatic models are burdened with great uncertainty in reproducing precipitation (Szwed 2017). Therefore, evaluation of current and future (projected) tendencies in precipitation totals (monthly, seasonal, or annual) as well as the changes in the annual cycle of precipitation will allow estimating the water availability across the area of Poland. Furthermore, the assessment of changes in every element of the hydrological cycle may lead to more effective, integrated water resource management at regional and national scales.

The present paper examines a set of long time series of precipitation characteristics in Poland, based on monthly values of precipitation at 50 meteorological stations in the periods 1951-2013. The precipitation characteristics include precipitation unevenness index $\left(\mathrm{I}_{\mathrm{PU}}\right)$, annual, seasonal, and monthly precipitation totals, share of precipitation in an individual month within the annual sum, share of summer (JJA) precipitation to annual precipitation totals, share of winter (DJF) precipitation to annual precipitation totals, the ratio of precipitation in summer (JJA) to winter (DJF), as well as the ratio of precipitation between the warmer (AMJJAS) and the colder (ONDJFM) seasons. The research attempts to confirm or deny the hypothesis that the pluvial regime in Poland has changed during the analyzed recent period of six decades.

\section{Data}

The study uses a set of 50 time series of monthly precipitation totals from 1951 to 2013, gathered at observation stations in Poland. Monthly data are evaluated based on daily values of 
precipitation delivered by the Polish Meteorological and Hydrological Service (the Institute of Meteorology and Water Management-State Research Institute, Polish acronym: IMGW-PIB) for the purpose of the CHASE-PL Project (www. chase-pl.pl). The basic criteria for selection of stations for analysis were (i) the length and completeness of the available time series of records and (ii) the spatial distribution of stations - covering most evenly (if possible) the whole territory of Poland. The meteorological stations used in the present study are mapped in Fig. 1.

For the future horizon (2061-2090), time series of monthly data of precipitation stems from multi-model ensemble climate projections obtained within the ENSEMBLES Project of the 6th Framework Programme of the EU (Van der Linden and Mitchell 2009). They are calculated based on the simulation results of daily precipitation from five ENSEMBLES regional climate models for grid cells containing analyzed meteorological stations. The regional models from the ENSEMBLES Project used in this study are as follows, in alphabetical order, C4IRCA3 from the Rossby Centre (Norrköping, Sweden), CLM from the ETH (Zurich, Switzerland), KNMI-RACMO2 from the Royal National Meteorological Institute (De Bilt, the Netherlands), METO-HC from the Met Office's Hadley Centre (Exeter, UK), and MPI-M-REMO from the Max Planck Institute (Hamburg, Germany) (Van der Linden and Mitchell 2009). Regional climatic models were generated, based on two different global circulation models (GCMs). Regional models C4IRCA3, ETHZ-CLM, and METO-HC are based on the global model METO-HC standard, while models MPI-MREMO and KNMI-RACMO2 are calibrated based on the global circulation model ECHAM of the fifth generation (Van der Linden and Mitchell 2009). All of the used ENSEMBLES regional climate models cover Europe with a spatial resolution of about 25 by $25 \mathrm{~km}$ and correspond to a specific SRES emission scenario, A1B (IPCC 2000).

In addition, the same precipitation parameters were analyzed at several stations in the neighboring countries (four stations east and four stations west of the Polish border). For the present time horizon (1951-2013), the data comes from the European Climate Assessment and Dataset Project website (Klein Tank et al. 2002). Future projections were taken from the results of ENSEMBLES models, same as for the stations in Poland. These several stations allowed observing whether changes in precipitation characteristics - similar to those observed in Poland - are also typical for more oceanic (West) and more continental climates (East of Poland). A list of analyzed measuring stations outside of Poland is presented in Table 1.

\section{Methods}

Different characteristics of precipitation are calculated for the average conditions in the present (1951-2013) and the future
(2061-2090) climates. All calculations for the periods 19512013 are based on the observation values, while for the future 2061-2090, the simulations of the five regional climate models are used.

Precipitation is extremely difficult to model due to strong temporal and spatial variability. While different regional climatic models reconstruct annual sums of precipitation for the area of Poland fairly well, they perform poorly when it comes to displaying seasonal and monthly distribution of precipitation. So, projections for the future bear considerable uncertainty. Nevertheless, earlier validations (Szwed 2015) indicated that MPI-M-REMO model represents historical precipitation conditions in Poland better than the others. That is why in this research, the future precipitation conditions are presented in two ways: (i) as an average value of the simulations from five regional climate models and (ii) as a single simulation value for the MPI-M-REMO model. The future conditions of precipitation are compared to the trends/tendencies in the distribution of precipitation observed in past-to-present. They try to answer question, whether the tendency observed today is likely to continue in the future.

Climate (including precipitation) of the temperate zone, observed in Poland, is dominated by strong annual and seasonal variability. In order to describe the evenness or unevenness of distribution of precipitation during a year, every meteorological station is described by precipitation unevenness index $\left(I_{P U}\right)$ by Chromov (1968). The index equation is as follows:

$I_{P U}=\frac{\sum_{m=1}^{m=12}\left|P_{m-}-\frac{P_{a}}{12}\right|}{P_{a}} \times 100$

where $P_{m}$ is the monthly precipitation total and $P_{a}$ is the annual precipitation total (both in $\mathrm{mm}$ ). The obtained values of $I_{P U}$ allow classifying the area based on precipitation regime. Thus, the lowest value of $I_{P U}$ corresponds to the most even distribution of precipitation. The value of $I_{P U}$ from 0 to 20 represents an even distribution, 21 to 40 represents moderately uneven distribution, 41 to 60 represents medium uneven distribution, etc., (Chromov 1968).

The other analyzed characteristics of precipitation include the following:

- annual, seasonal, and monthly precipitation totals;

- share of precipitation in an individual month within the annual sum;

- share of summer (JJA) precipitation to annual precipitation totals

- share of winter (DJF) precipitation to annual precipitation totals

- the ratio of precipitation in summer (JJA) to winter (DJF);

- the ratio of precipitation in warmer season (AMJJAS) to colder one (ONDJFM). 
Fig. 1 Locations of Polish meteorological stations used in this research

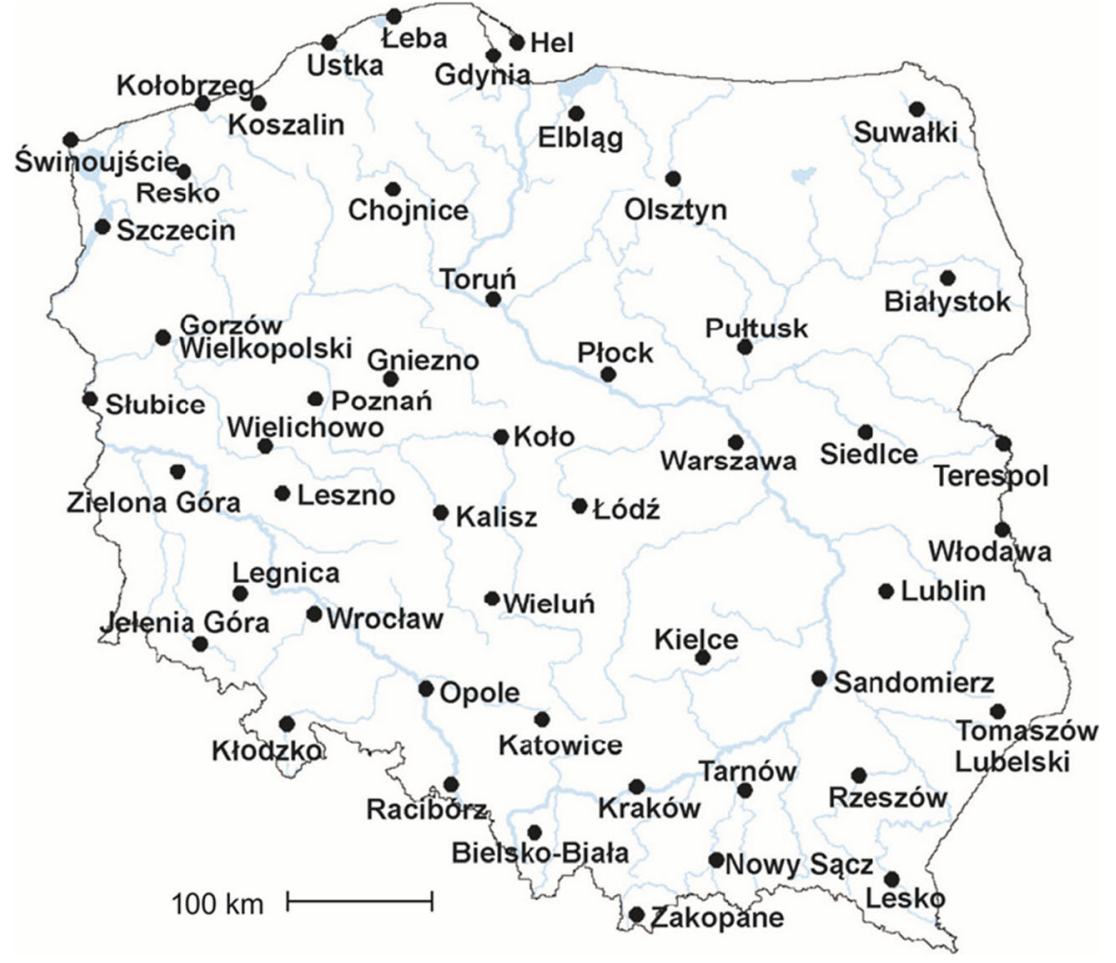

The observed behavior of time series of precipitation is complex and not easy to interpret due to strong inter-year and seasonal (intra-year) variability. In order to detect existing changes/trends in time series of precipitation data, the Hydrospect 2.0 software was used (Radziejewski and Kundzewicz 2000). Trend detection was carried out using parametric (e.g., regression) and non-parametric tests (e.g., of Mann-Kendall). Statistical significance of trend for every station at various levels was determined. The obtained results of trend detection in the observed data were compared to the projections for the future.

The IDRISI GIS platform (Eastman 2009) was used to present the spatial variability of precipitation characteristics. For their interpolation, ordinary kriging with matching a spherical function was used. However, considering a small scale of the maps, they are rather of an illustrative nature.

\section{Results}

\subsection{Annual sum of precipitation}

In the periods of 1951-2013, mean annual precipitation for Poland, based on 50 analyzed stations, amounted to $618 \mathrm{~mm}$ and varied from $480 \mathrm{~mm}$ in Leszno to more than $1000 \mathrm{~mm}$ in Zakopane. In general, the precipitation in the area of central lowland of Poland is the lowest. The precipitation grows to the North and South (Fig. 2a). It has been observed that in present climate, annual sums of precipitation are slightly growing in Poland; however, these changes are not statistically significant in the entire area. More distinct increases are observed in the northern part of Poland (Fig. 2b).

Based on five climate models, as well as on a single MPI-M-REMO climate model, further growth of annual sum of precipitation is predicted in the future years 20612090 , especially in the northern part of the country. The annual precipitation totals below $600 \mathrm{~mm}$ are not projected at all (see Fig. 3a, b). Average projection from five models points that in most areas of Poland, annual precipitation increases will be $200-300 \mathrm{~mm}$ and the highest is in the high mountains - over $400 \mathrm{~mm}$. The projection of the MPI-M-REMO model differs significantly from the average projection from five models. This model predicts the highest increases of

Table 1 The meteorological stations located outside of Poland used in this research

\begin{tabular}{llll}
\hline Station & Latitude & Longitude & Elevation \\
\hline Baranovici (Belarus) & $53^{\circ} 06^{\prime} \mathrm{N}$ & $26^{\circ} 00^{\prime} \mathrm{E}$ & $194.0 \mathrm{~m}$ \\
Drezden (Germany) & $51^{\circ} 06^{\prime} \mathrm{N}$ & $13^{\circ} 41^{\prime} \mathrm{E}$ & $246.0 \mathrm{~m}$ \\
Lviv (Ukraine) & $49^{\circ} 49^{\prime} \mathrm{N}$ & $23^{\circ} 57^{\prime} \mathrm{E}$ & $323.0 \mathrm{~m}$ \\
Magdeburg (Germany) & $52^{\circ} 06^{\prime} \mathrm{N}$ & $11^{\circ} 35^{\prime} \mathrm{E}$ & $76.0 \mathrm{~m}$ \\
Pinsk (Belarus) & $52^{\circ} 07^{\prime} \mathrm{N}$ & $26^{\circ} 07^{\prime} \mathrm{E}$ & $146.0 \mathrm{~m}$ \\
Potsdam (Germany) & $52^{\circ} 23^{\prime} \mathrm{N}$ & $13^{\circ} 03^{\prime} \mathrm{E}$ & $81.0 \mathrm{~m}$ \\
Schwerin (Germany) & $53^{\circ} 38^{\prime} \mathrm{N}$ & $11^{\circ} 23^{\prime} \mathrm{E}$ & $59.0 \mathrm{~m}$ \\
Vilnius (Lithuania) & $54^{\circ} 38^{\prime} \mathrm{N}$ & $25^{\circ} 06^{\prime} \mathrm{E}$ & $156.0 \mathrm{~m}$ \\
\hline
\end{tabular}




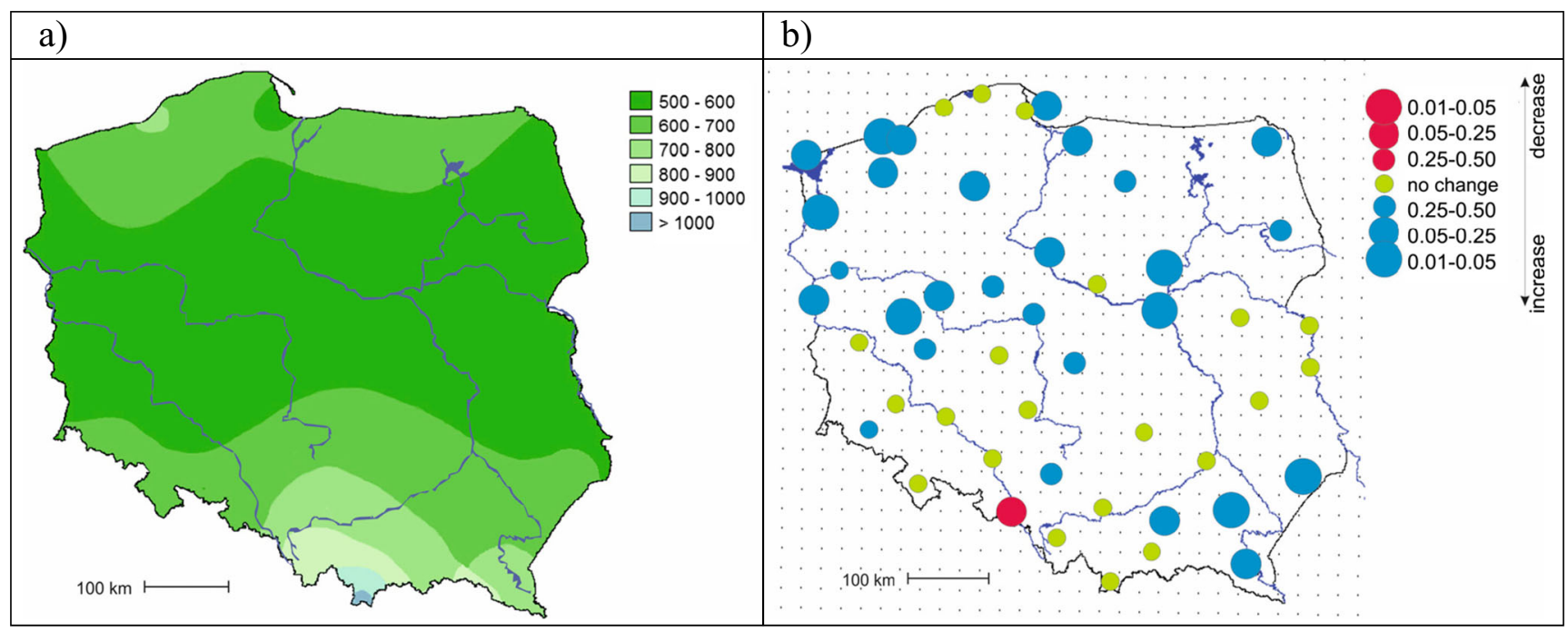

Fig. 2 Annual precipitation total in the periods 1951-2013 in Poland a mean values, in mm, b significance level of changes in the annual sum of precipitation in the periods 1951-2013 based on Mann-Kendall test

annual precipitation total on the coast (over $400 \mathrm{~mm}$ ), while the decreases of over $200 \mathrm{~mm}$ in the highest mountains. In most parts of Poland, this projection foresees increases of precipitation in the range of $100-300 \mathrm{~mm}$, slightly higher to the north (Fig. 3c, d).

If we look at the results of analyses for countries neighboring Poland, it turns out that presently, no changes in annual precipitation totals have been observed west of Poland; while east of Poland, there have been noted statistically significant increases at the level of 0.01 for two stations (Baranovici, Pinsk) and of 0.05 for two other stations. Projections for the future point to an increasing trend in the annual precipitation totals for all the stations outside of Poland (both in the east and west). For each station, the average value of the annual precipitation total in the future from five models and from each model separately is higher than the average from the periods of 1951-2013.

\subsection{Precipitation unevenness}

Presently, based on the precipitation unevenness index $\left(\mathrm{I}_{\mathrm{PU}}\right)$, intra-year variability of precipitation on the territory of Poland can be described as moderately and medium-unevenly distributed. The mean value of $\mathrm{I}_{\mathrm{PU}}$ for 50 stations in Poland is 31 . The lowest $\mathrm{I}_{\mathrm{PU}}$ values (marking even distribution) are found for the north-western part of Poland while the highest for the South (Fig. 4a). The distribution of precipitation is uneven during a year, because the summer precipitation is higher than the winter one. The most uneven distribution of precipitation was noted for the 10-year periods of 1951-1960; however, no statistically significant changes in the precipitation unevenness index are observed in the whole periods of 19512013 at the 0.05 level. Some weaker tendencies (to more even distribution during a year) were detected in a few stations (Fig. 4b). Based on climate model simulations, the tendency to more even distribution in a year should continue in the future. The expected mean value of $\mathrm{I}_{\mathrm{PU}}$ for Poland in the future is 16.5 based on five climate models, while about 15 based on MPI-M-REMO model. In the future, there is almost no spatial diversity in the value of $\mathrm{I}_{\mathrm{PU}}$ across Poland.

Several stations located outside Poland analyzed in this paper are characterized by a medium uneven distribution of precipitation with the values of index $\mathrm{I}_{\mathrm{PU}}$ varying from 42 to $47 \%$ and it does not tend to change during the periods $1951-$ 2013. However, projections for the future predict a clear decline in the value of the unevenness index, estimating it (an average of five models) at a dozen or so percentages in all locations, indicating an even distribution of precipitation over the year.

\subsection{Summer precipitation total (JJA)}

Summer precipitation totals in the periods of 1951-2013 seem to be stable. Neither trends nor even weak tendencies in time series of summer precipitation totals were detected around Poland. There is only one exception from this rule-for the time series of Pultusk station, an increasing trend was detected of the significance level of 0.05 . Of course, the lack of changes in the summer precipitation totals does not indicate their stable share in the total annual sum. However, there are no changes on majority of stations. Some stations showed weak decreasing trends. Such a tendency is most visible in the south of Poland (see Fig. 5). However, the mean share of summer to annual precipitation for Poland in the periods of 1951-2013 (based on 50 stations) reaches $37.7 \%$, and varies from about $31 \%$ in coastal areas to more than $43 \%$ in the south. There are projected further decreases of share of summer precipitation in the future. The mean share of summer precipitation in the 
annual total is equal to 24 and $28 \%$, based on five climate models and MPI-M-REMO model, respectively.

As far as the stations outside Poland are concerned, to the west, there have been noted decreases in summer precipitation total and their share in the annual precipitation total for the periods 1951-2013 (including the station of Schwerin, where the decrease is statistically significant at the 0.05 level). In the east, no changes have been recorded. However, projections for the future suggest that by the end of the century, the share of summer precipitation will decrease by about $10 \%$ and will amount to $21-26 \%$. These are values close to those estimated for Poland.

\subsection{Winter precipitation total (DJF)}

In this research, winter is interpreted as the sequence of DJF months, where D (December) belongs to the preceding calendar year. This way, the first winter that can be described is the winter of 1952 understood as December 1951, January 1952, and February 1952.

As to the winter precipitation total, Poland is divided into two parts. In the north-west and west areas, there are clear increases in the sum of winter precipitation. At ten stations, these increases are statistically significant at the 0.05 level of and at other stations; some weaker increasing tendencies are detected. For the east and south-east, no changes in winter sum of precipitation are observed. The increases or stability in total winter precipitation lead to increase in their share in annual sum of precipitation, especially visible in the west (Fig. 6). The mean share of winter to annual precipitation for Poland in the analyzed period is equal to $17.4 \%$, and varies from about $12.6 \%$ in Kłodzko (the smallest share has been recorded for the south-west) to above $22.4 \%$ in Resko (the greatest share of winter precipitation is noted in the north-

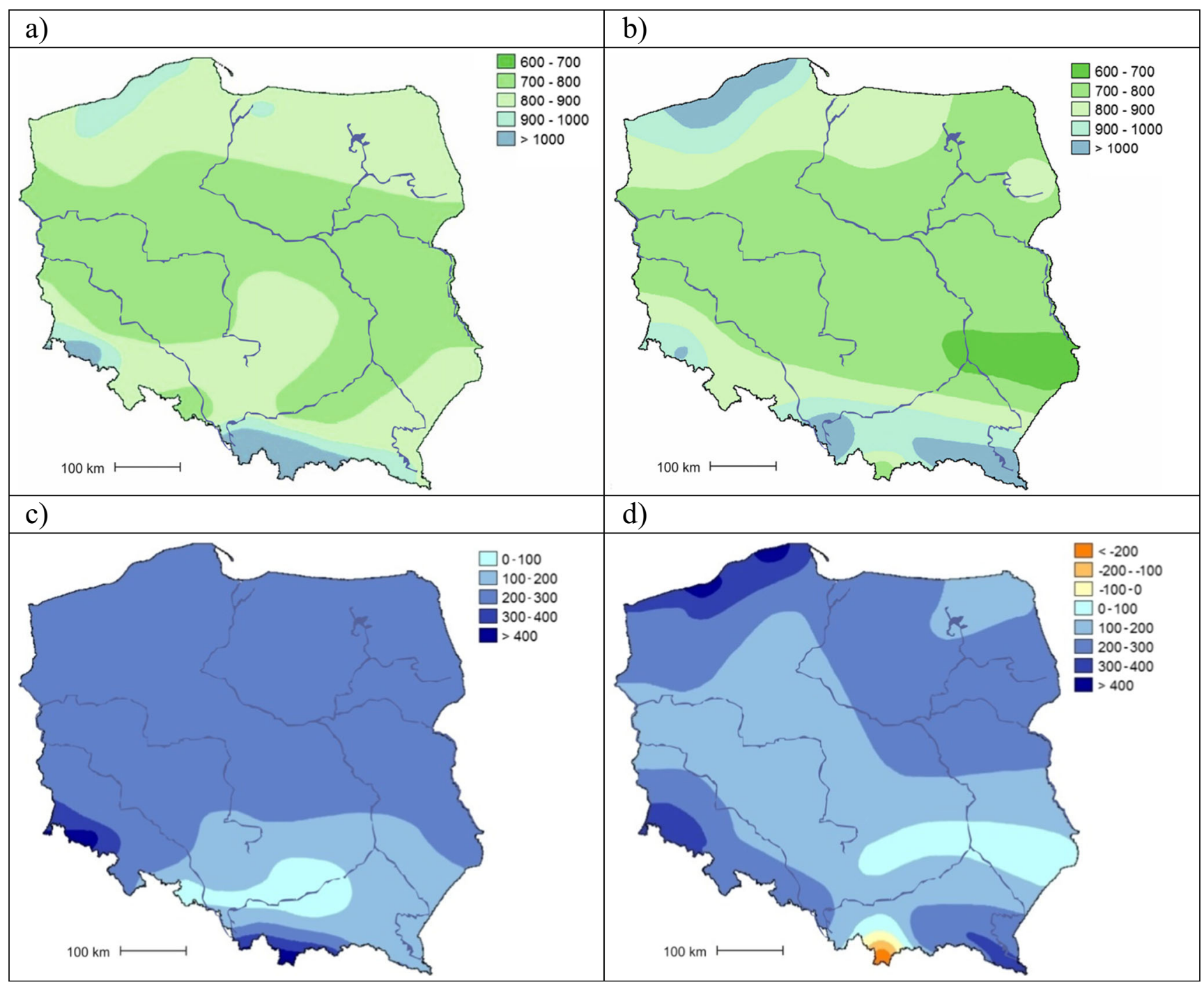

Fig. 3 Annual precipitation totals in the future (2061-2090) in Poland, in $\mathrm{mm}$, a average value for five climate models, $\mathbf{b}$ MPI-M-REMO model, $\mathbf{c}$ difference in relation to the present based on five climate models, and $\mathbf{d}$

difference in relation to the present based on MPI-M-REMO model (negative values mean less precipitation) 
west). For the future, there are projected further increases of the share of winter precipitation. The mean share of winter precipitation in the annual total is equal to 26.6 and $24.2 \%$, based on five climate models and MPI-MREMO model, respectively. Comparing the projected changes in the share of winter and summer precipitation to the annual total, one can state that the presently observed changes are likely to continue.

Currently, analyses of winter precipitation in the close vicinity of Poland show a weak increasing tendency, more pronounced to the north. Nevertheless, none of these tendencies are strong enough to be statistically significant at 0.05 level. Projections for the future, however, suggest continuation of such tendencies and increases of winter precipitation total and in the share of winter precipitation in the annual sum in the periods 2061-2090.

\subsection{Variability in individual months}

Analysis of the monthly sums of precipitation shows that the most variable precipitation is observed in July and June, while the most stable is from January to March. The share of June/July precipitation as a rule varies to more than $40 \%$ within annual sum of precipitation, while the share of winter months to no more than a dozen or so percent each.

For the periods of 1951-2013, the absolute maximum share of July precipitation within the annual sum was noted in Sandomierz in 2011 and reached the value of $60.0 \%$, while the absolute maximum share of winter monthJanuary - was observed in Stubice in 1976 and amounted to $26.6 \%$. Figure 7 is an example of these characteristics for Toruń station.

\subsection{Share of march precipitation}

As mentioned before, observed annual sums of precipitation have been slightly growing in Poland. It turns out that the most visible increases have been observed during months of colder half-year, especially in March. For the northern and central part of Poland, the statistically significant trend of March precipitation total in the periods 1951-2013 was detected (Fig. 8b). Further grow of March precipitation of about $20 \mathrm{~mm}$ in the entire area of Poland is projected by climate models for 2061-2090. It will also cause the increase of share of March precipitation within the annual precipitation total in the future.

To recapitulate, the mean March precipitation total in Poland (for 50 stations) is presently $30.7 \mathrm{~mm}$, while the projection for the future is $63.9 \mathrm{~mm}$ - mean value for the five models - and $58.3 \mathrm{~mm}$ - based on MPI-M-REMO model. Next, the mean share of March precipitation within annual sum is presently $5.5 \%$. Based on five models, it will grow to $7.7 \%$ in the future (or to $7.0 \%$ if taking MPI-M-REMO model only), (see Figs. 8 and 9a, b). In general, the smallest increases of share of March precipitation in the annual precipitation total in the future in relation to the present are projected in the west/ north-west and will increase in the east/south-east direction (Fig. 9c, d).

Stations outside of Poland perfectly fit in the above-described picture of changes in March precipitation. March increases were recorded only for Potsdam and Schwerin stations (weak trends not statistically significant at the 0.05 level), which corresponds to the greatest changes in north-western Poland. No changes were detected at other stations. However, projections for the future say that in the next time horizon, the changes will cover all analyzed

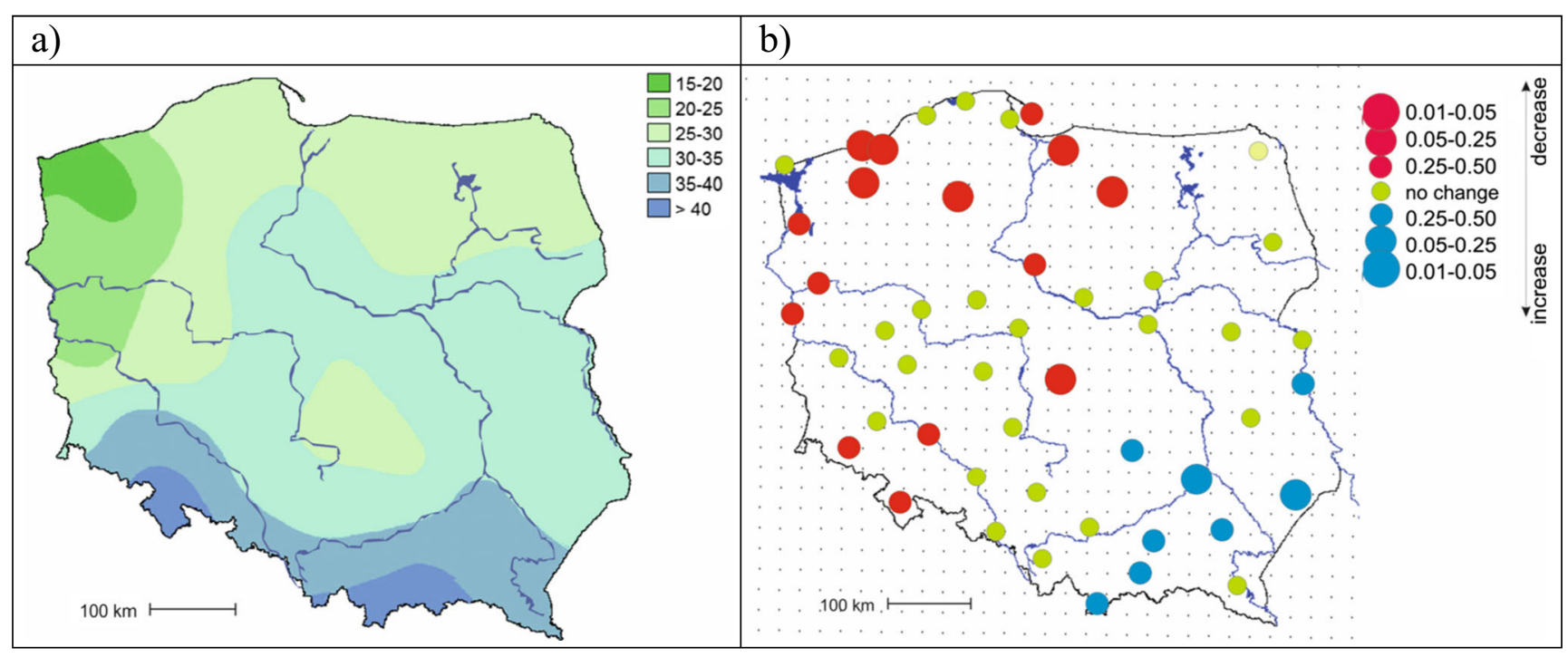

Fig. 4 The value of the precipitation unevenness index for the periods 1951-2013, a mean value for the analyzed period, $\mathbf{b}$ significance level of changes in the precipitation unevenness index in the periods 1951-2013 based on Mann-Kendall test 
Fig. 5 Significance level of changes in the share of summer (JJA) to annual precipitation in the periods 1951-2013 based on Mann-Kendall test

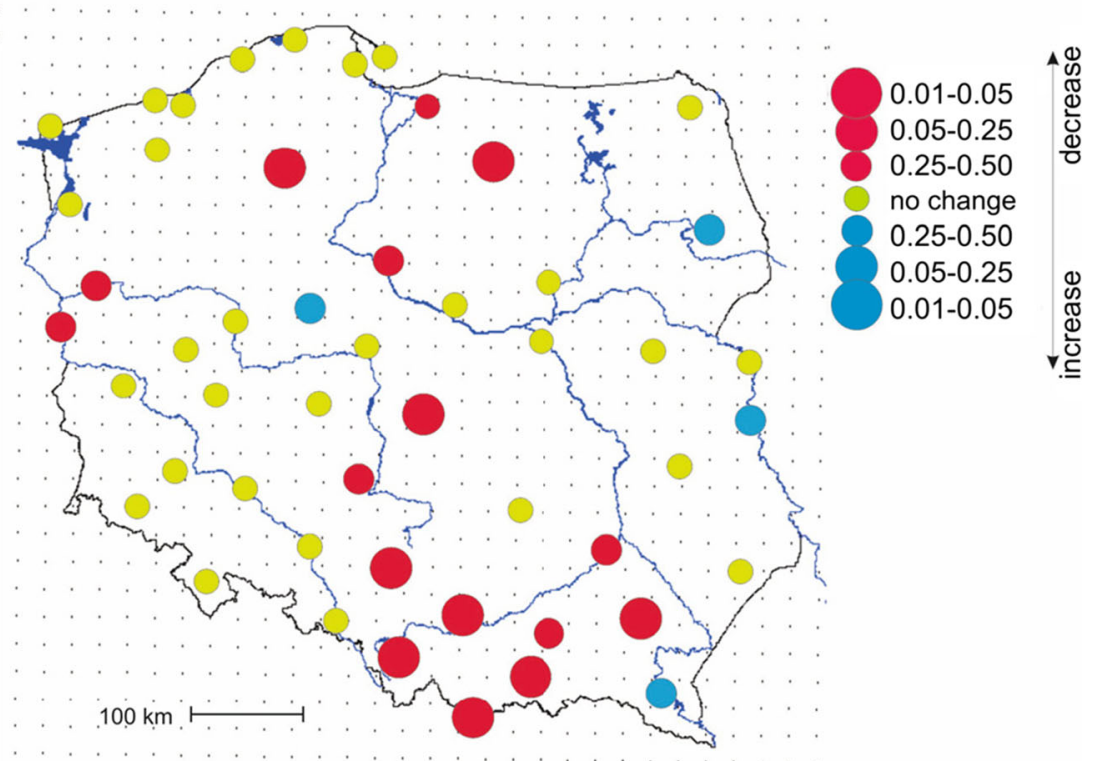

stations and the share of March falls will be similar to that estimated for Poland.

\subsection{Changes in annual cycle of precipitation}

The increase of winter precipitation and decrease of summer precipitation (although not statistically significant) affect the proportion of summer (JJA) to winter (DJF) precipitation, whose mean values for the present and future are 2.2 and 1.2 , respectively. The same characteristics for warmer halfyear (AMJJAS) and colder half-year (ONDJFM) take the values of 1.8 and 1.1 , respectively. Presently, the smallest differences between summer and winter sum of precipitation are noted for the north-western part of Poland, while the highest for the south. This corresponds to the $\mathrm{I}_{\mathrm{PU}}$ value, presented above in this paper (see Fig. 4). Pearson correlation coefficient between the ratio of JJA to DJF precipitation and the IPU value is about 0.82 . No statistically significant changes of the proportion of summer (JJA) to winter (DJF) precipitation totals have been detected for the periods of 1951-2013, but some weak tendencies for a few stations have been noted-Fig. 10a. Similar (slightly visible) changes are noted for the ratio of precipitation in warmer half-year to colder one (Fig. 10b).

These tendencies are projected to continue in the future. As was mentioned before, the unevenness of
Fig. 6 Significance level of changes in the share of winter (DJF) to annual precipitation in the periods 1952-2013 based on Mann-Kendall test

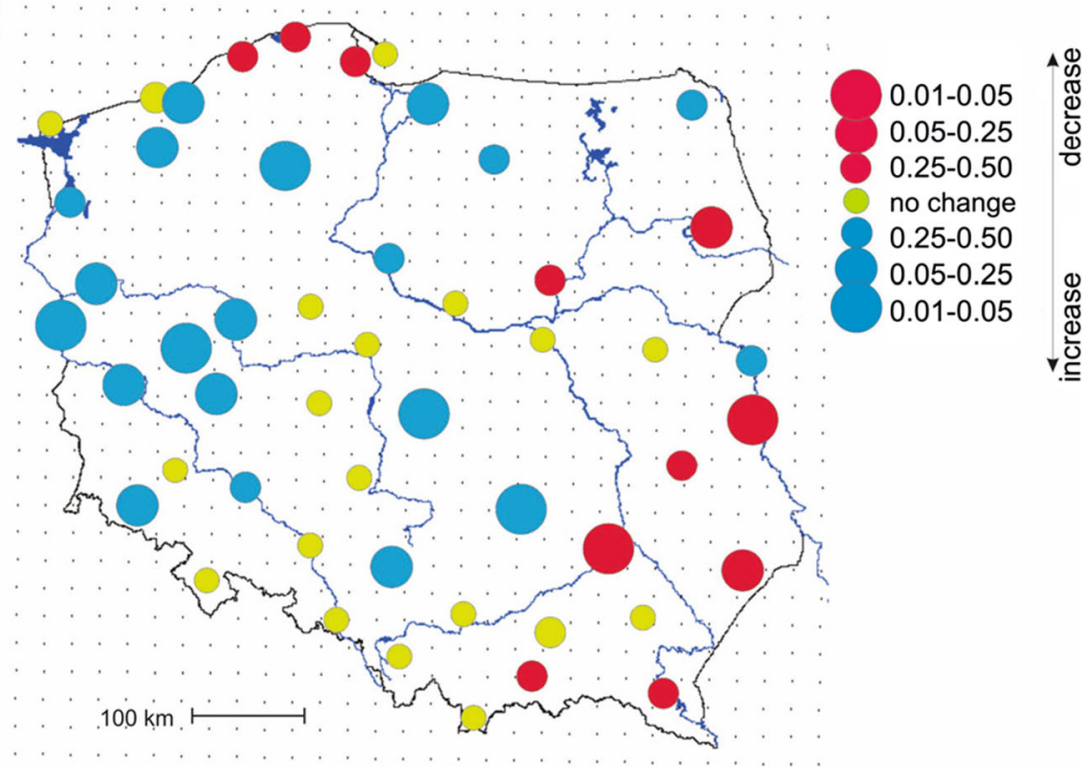




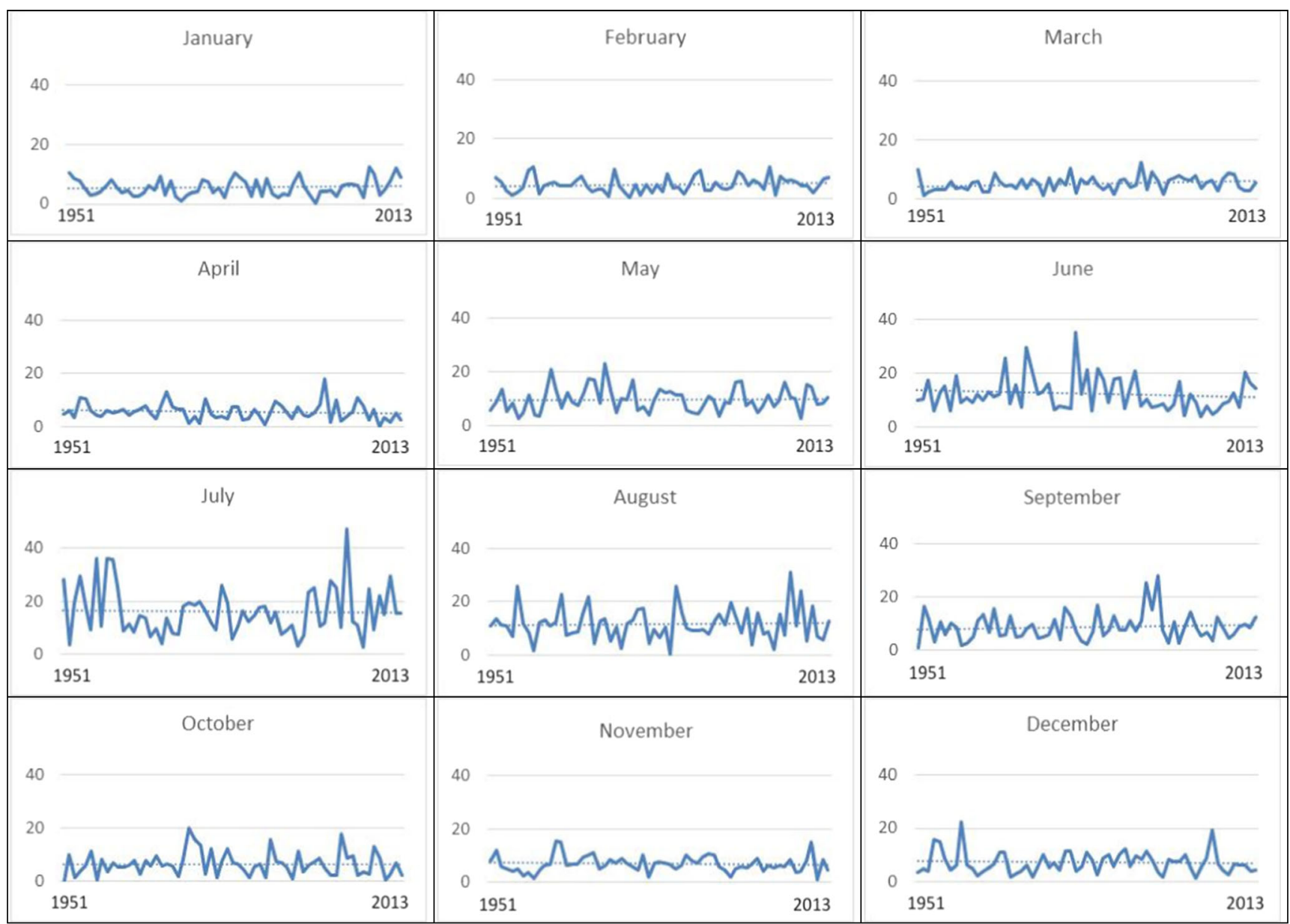

Fig. 7 The share of monthly sum of precipitation within the annual sum in the periods 1951-2013 for Torun station, in \%

precipitation will decrease in the future, so the proportion of JJA to DJF precipitation as well as the proportion of AMJJAS to ONDJFM precipitation also is projected to decrease.

\section{Concluding remarks}

It can be stated - based on this research - that due to the climate change, annual sums of precipitation have been already

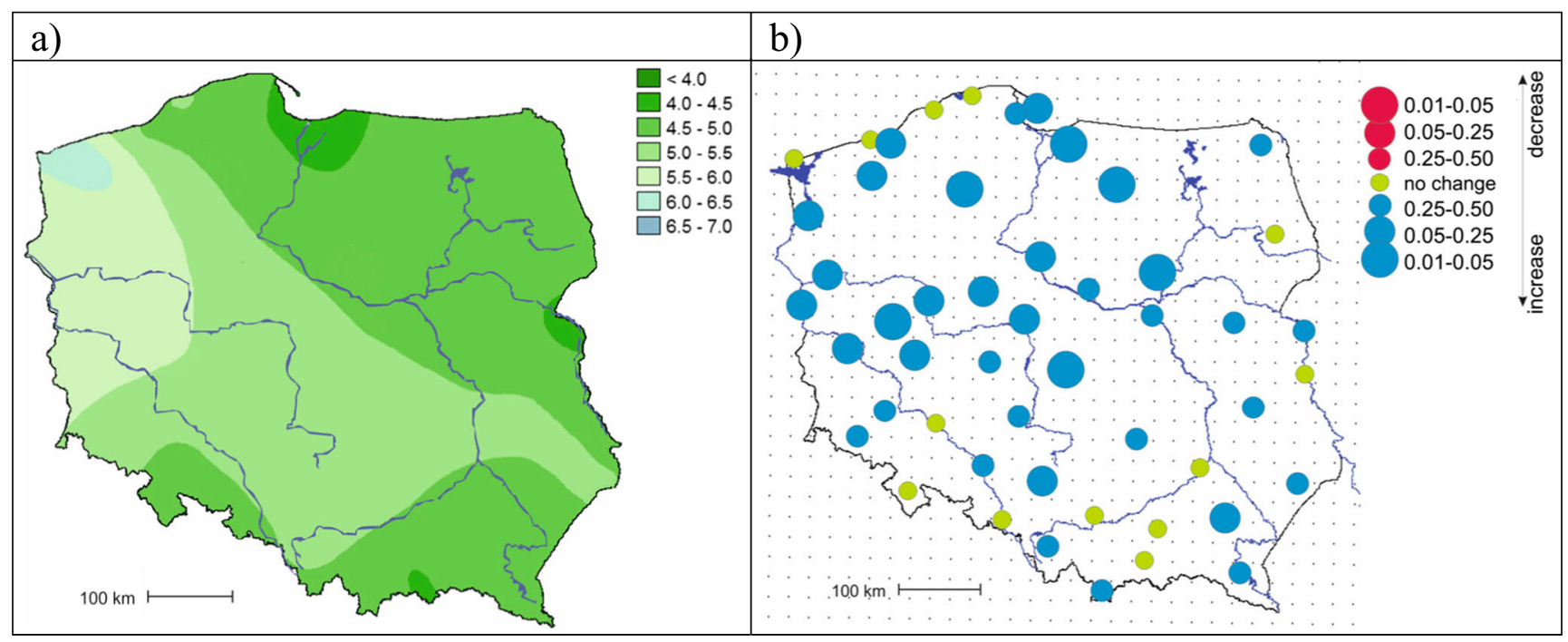

Fig. 8 The ratio of March sum of precipitation in the annual sum in the periods 1951-2013 a mean value for the analyzed period, $\mathbf{b}$ significance level of changes in the ratio of March sum of precipitation in the annual sum in the periods 1951-2013 based on Mann-Kendall test 


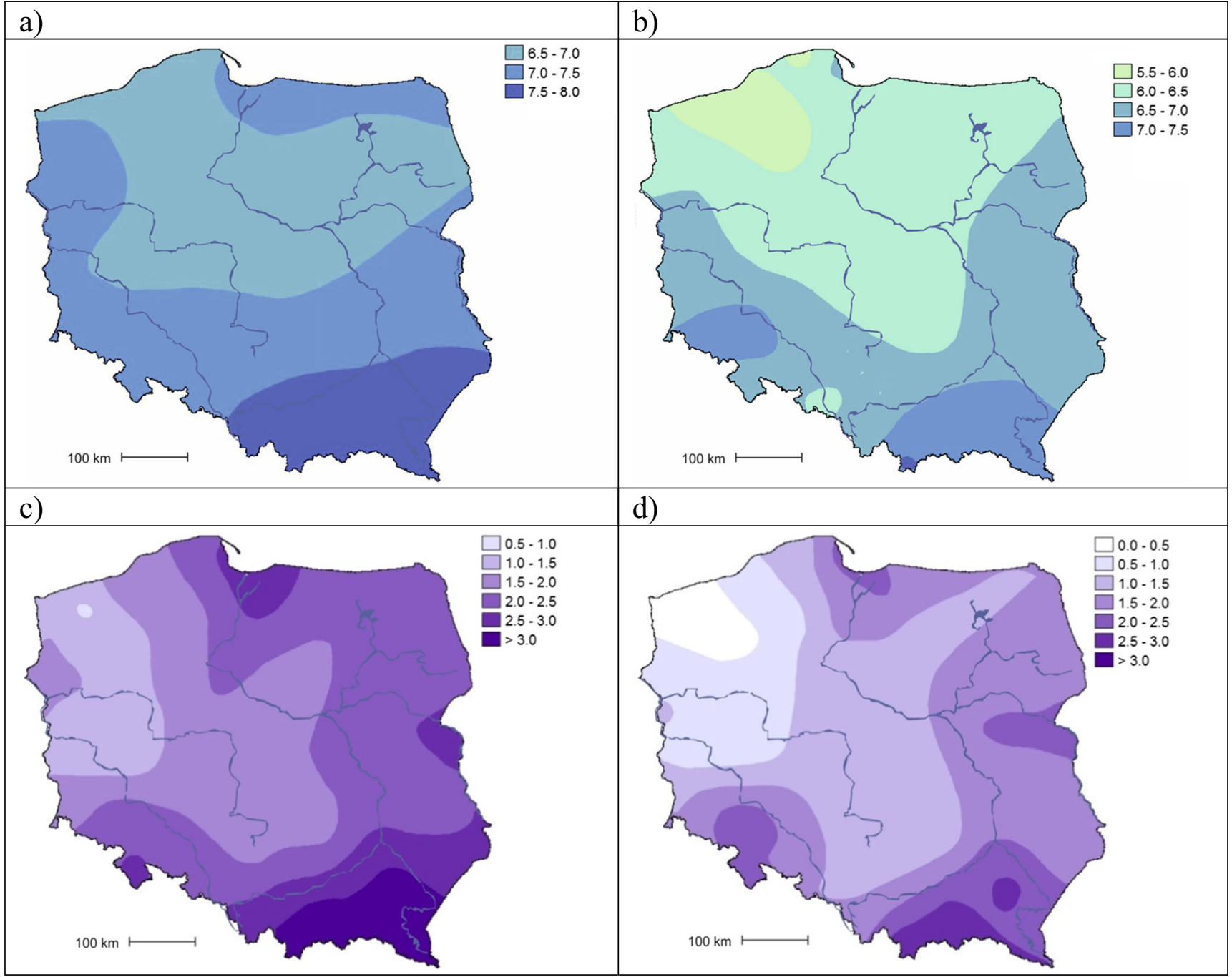

Fig. 9 The ratio of March sum of precipitation in the annual sum in the future (2061-2090), a average value for five climate models, b MPI-M-REMO model, $\mathbf{c}$ difference in relation to the present based on five climate models, and $\mathbf{d}$ difference in relation to the present based on MPI-M-REMO model

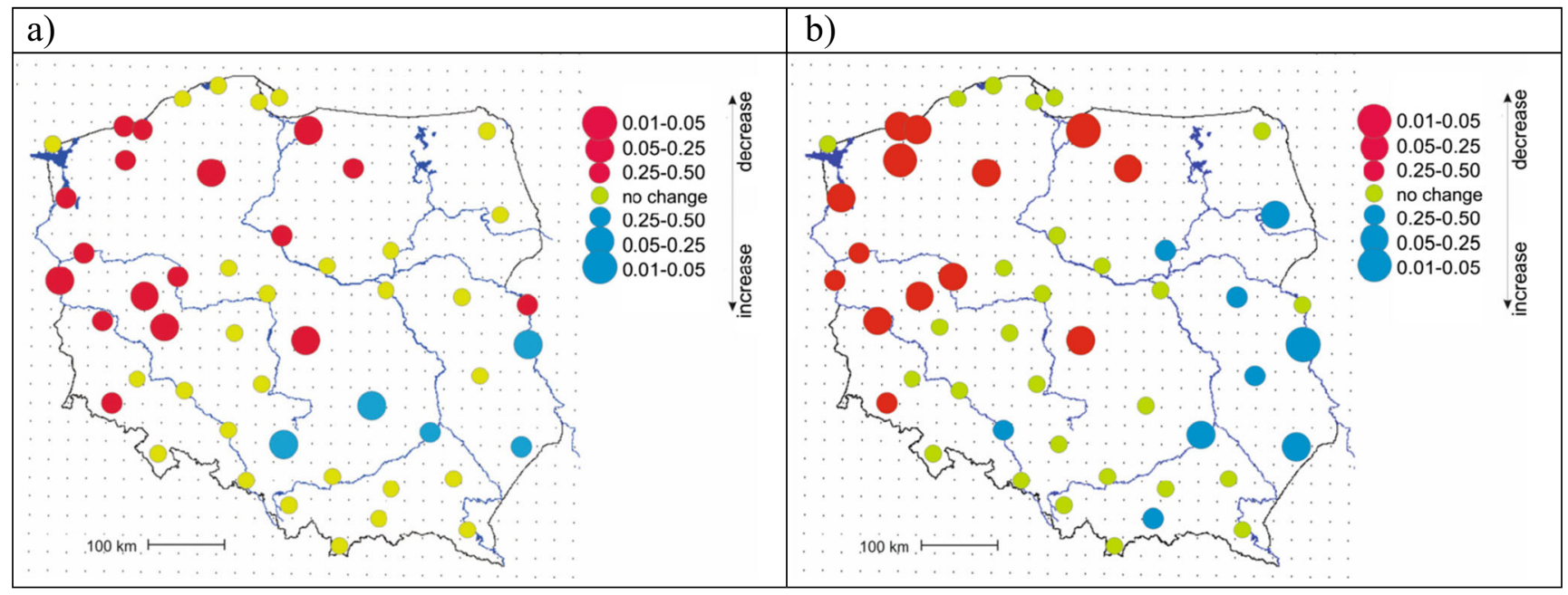

Fig. 10 a Significance level of changes in the ratio of JJA to DJF precipitation in the periods 1951-2013 on Mann-Kendall test, and b Significance level of changes in the ratio of AMJJAS to ONDJFM precipitation in the periods 1951-2013 based on Mann-Kendall test 
slightly growing in Poland. However, these changes are not statistically significant in the entire area. More distinct growth is observed in the northern part of Poland. Such a result is in line with other research studies. Many authors have sought precipitation changes. A slight but insignificant increase in precipitation totals was typically observed (Żmudzka 2002; Degirmendžić et al. 2004; Kożuchowski 2004, etc.). This coincides also with the results determined by Wybig (2009) who claims that precipitation in Poland did not change greatly in the second half of the twentieth century. Yet, it is necessary to remember that the detected trend often depends on the period selected for analysis. For example, Brazdil and Kożuchowski (1986) analyzed precipitation in the periods of 1881-1980 and found an increasing trend from 1881 up to about the 1920 s, followed by a drop with the minimum in 1950s. However, for the whole analyzed period, they noticed some increasing trend.

Based on the precipitation unevenness index $\left(\mathrm{I}_{\mathrm{PU}}\right)$, intrayear variability of precipitation on the territory of Poland can be described presently as moderately and medium-unevenly distributed. The most even (flat) distribution of precipitation was found for the north-western part of Poland, while a more uneven for the south. No statistically significant changes in the precipitation unevenness index are observed in the whole periods of 1951-2013 at the significance level of 0.05; however, a tendency to more even distribution within a year is likely to continue in the future.

Summer precipitation total in the periods of 1951-2013 seems to be stable. Neither trends nor even weak tendencies in time series of total summer precipitation were detected around Poland. It does not mean, however, that the share of summer precipitation in the total annual sum is stable/invariable. There are no changes on majority of stations. Some stations showed weak decreasing trends in the share of summer precipitation within the annual sum. Such a tendency is most visible in the southern areas of Poland.

In the north-west and west areas, there are clear visible increases in winter precipitation totals. At some stations, increases are statistically significant at the 0.05 level. For the East and South-East, no changes in winter precipitation totals are observed. In general, an increase in the share of winter precipitation within the annual sum is observed.

As to the seasonal precipitation totals described by other researchers, Skowera et al. (2014) report its cyclicity in the years 1971-2010. Czarnecka and Nidzgorska-Lencewicz (2012) found in most parts of the country a small, nonsignificant upward trend in precipitation in spring and autumn and a decrease in summer. Bochenek (2012) noted changes in rainfall patterns and a declining share of summer precipitation in the total annual sum. The most ambiguous are the changes in proportion of summer to winter precipitation total. They depend on the region as stated by Skowera et al. (2014).
Analysis on variability of monthly precipitation totals shows that, in the periods of 1951-2013, the most variable precipitation is observed in July and June, while the most stable is from January to March. The share of June/July precipitation as a rule varies to more than $40 \%$ within annual sum of precipitation, while the share of winter months to no more than a dozen or so percent each. This agrees with the results determined by Kasperska-Wołowicz et al. (2016). They reported the highest average sums of precipitation in July and the lowest in February, minimum monthly precipitation between January and April, and in October, and maximum totals in July.

The most visible increases in the monthly sums as well as in the share of monthly precipitation within the annual sum are observed during colder half-year, especially in March. The statistically significant trend of March contribution to annual precipitation in the periods 1951-2013 was detected for several stations in the northern and central part of Poland. Weaker tendencies or even their lack are noticed in the remaining regions. The other research studies claim that there is a weak increasing trend of several monthly sums (e.g., upward trends were found in August by Skowera et al. 2014), but this is not significant, except for March (Degirmendžić et al. 2004; Żmudzka 2002; Świątek 2011).

Despite the fact that trends of monthly totals are not significant, a distinct change in the seasonal precipitation pattern has taken place. The increase of winter precipitation and decrease of summer (although not statistically significant yet) change the proportion of summer (JJA) to winter (DJF) precipitation. At present, smallest differences between summer and winter sum of precipitation are noted in the northwestern part of Poland, while the highest for the South. Even if no statistically significant changes in the ratio of JJA precipitation to DJF precipitation have been detected (for the periods of 1951-2013), some weaker tendencies for a few stations have been noted. Slightly more visible changes are noted for the ratio of precipitation in warmer half-year to colder one.

Projections for the future point to further disadvantageous changes in the seasonal distribution of precipitation in Poland. These findings are consistent with the results of Osuch et al. (2016). They stated that projections of precipitation for the future based on SPI values (SPI-Standardized Precipitation Index) indicate an increase in the degree of wetness (better water availability) during the winter months and a decrease in the summer period (more water scarcity).

Moreover, based on this research, one can speculate that all the detected trends and weaker signals/tendencies observed today could continue in the future. The annual precipitation totals are projected to be growing; precipitation in warmer season will further decrease and in colder one will increase. As a result, a shift of precipitation from warmer towards colder season will be continued. It is a really unfavorable 
tendency, because already in the present climate, many regions in Poland suffer shortage of water in the growing season and this situation may get even worse.

Acknowledgements The reported research has been carried out within the CHASE-PL (Climate change impact assessment for selected sectors in Poland) project of the Polish-Norwegian Research Program in the frame of Project Contract Pol-Nor/ 200799/90/2014. Observation data used in this work were provided by the Institute of Meteorology and Water Management-State Research Institute (IMGW-PIB).

Open Access This article is distributed under the terms of the Creative Commons Attribution 4.0 International License (http:// creativecommons.org/licenses/by/4.0/), which permits unrestricted use, distribution, and reproduction in any medium, provided you give appropriate credit to the original author(s) and the source, provide a link to the Creative Commons license, and indicate if changes were made.

\section{References}

Bochenek W (2012) Ocena zmian warunków opadowych na stacji naukowo-badawczej IGiPZ PAN w Szymbarku w okresie 40 lat obserwacji (1971-2010) i ich wpływ na zmienność odpływu ze zlewni Bystrzanki (Evaluation of precipitation at the IG\&SO PAS research station in Szymbark during 40-year period (1971-2010) and its impact on the variability of water runoff from the Bystrzanka stream basin). Woda-Środowisko-Obszary Wiejskie (IV-VI) 12 2(38):29-44

Brazdil R, Kożuchowski K (1986) Some aspects of precipitation variability in Poland in the period of 1881-1980. Scr Fac Sci Nat Univ Purk Brun 8(Geographia):365-382

Brienen S, Kapala A, Māchel H, Simmer C (2013) Regional centennial precipitation variability over Germany from extended observation records. Int J Climatol 33(9):2167-2184. https://doi.org/10.1002/joc. 3581

Chromov SP (1968) Meteorológia a klimatológia. 1. (Meteorology and Climatology 1.) vyd. Bratislava: Vydavaté́stvo slovenskej akadémia vied, $453 \mathrm{~s}$

Czarnecka M, Nidzgorska-Lencewicz J (2012) Wieloletnia zmienność sezonowych opadów w Polsce (multiannual variability of seasonal precipitation in Poland). Woda-Środowisko-Obszary Wiejskie (IVVI) 12 2(38):45-60

Degirmendžić J, Kożuchowski K, Żmudzka E (2004) Changes of air temperature and precipitation in Poland in the period 1951-2000 and their relationship to atmospheric circulation. Int J Climatol 24: 291-310

Eastman JR (2009) IDRISI Taiga. Clark Labs. Clark University, Worcester

Hänsel S, Petzold S, Matschullat J (2007) Precipitation trend analysis for Central Eastern Germany. In: Střelcová K, Škvarenina J, Blaženec $\mathrm{M}$ (eds), Bioclimatology and natural hazards, international scientific conference, Pol'ana nad Detvou, Slovakia, 17-20 Sept 2007, ISBN 978-80-228-17-60-8

Hundecha Y, Bardossy A (2005) Trends in daily precipitation and temperature extremes across western Germany in the second half of the $20^{\text {th }}$ century. Int J Climatol 25:1189-1202. https://doi.org/10.1002/ Joc. 1182

IPCC (2013) Summary for policymakers. In: Climate change 2013: the physical science basis. Contribution of Working Group I to the Fifth Assessment Report of the Intergovernmental Panel on Climate Change. In: Stocker TF, Qin D, Plattner G-K, Tignor M, Allen
SK, Boschung J, Nauels A, Xia Y, Bex V, Midgley PM (eds). Cambridge University Press, Cambridge

IPCC SRES, Nakićenović N, Swart R (Eds) (2000) Special report on emissions scenarios: a special report of working group III of the intergovernmental panel on climate change, Cambridge University Press

Ivanov S, Palamarchuk J, Pyshniak D (2009) Precipitation statistics in Ukraine: sensitivity to informational sources. In: Groisman PY, Ivanov SV (eds) Regional aspects of climate-terrestrial-hydrologic interactions in non-boreal eastern Europe. NATO Science for Peace and Security Series C: environmental security. Springer, Dordrecht

Kasperska-Wołowicz W, Smarzyńska K, Miatkowski Z, Bolewski T, Farat R (2016) Monthly precipitation patterns in a region vulnerable to climate-related hazards - a case study from Poland. Water 8:362. https://doi.org/10.3390/w8090362

Klein Tank AMG, Wijngaard JB, Können GP, Böhm R, Demarée G, Gocheva A, Mileta M, Pashiardis S, Hejkrlik L, Kern-Hansen C, Heino R, Bessemoulin P, Müller-Westermeier G, Tzanakou M, Szalai S, Pálsdóttir T, Fitzgerald D, Rubin S, Capaldo M, Maugeri M, Leitass A, Bukantis A, Aberfeld R, van Engelen AFV, Forland E, Mietus M, Coelho F, Mares C, Razuvaev V, Nieplova E, Cegnar T, Antonio López J, Dahlström B, Moberg A, Kirchhofer W, Ceylan A, Pachaliuk O, Alexander LV, Petrovic P (2002) Daily dataset of 20thcentury surface air temperature and precipitation series for the European climate assessment. Int J Climatol 22:1441-1453. Data and metadata available at http://www.ecad.eu

Kożuchowski K (2004) Zmienność opadów atmosferycznych w Polsce w XX i XXI wieku. (The variability of precipitation totals in Poland in twentieth and twentieth first century) In: Kożuchowski K (ed) Skala, uwarunkowania i perspektywy współczesnych zmian klimatycznych w Polsce, Wydawnictwo Biblioteka, Łódź, 47-58

Kyselý J (2009) Trends in heavy precipitation in the Czech Republic over 1961-2005. Int J Climatol 29:1745-1758. https://doi.org/10.1002/ joc. 1784

Murawski A, Zimmer J, Merz B (2016) High spatial and temporal organization of changes in precipitation over Germany for 1951-2006. Int J Climatol 36(6):2582-2597. https://doi.org/10.1002/joc.4514

NOAA National Centers for Environmental Information (2017) State of the climate: global climate report for annual 2016, published online January 2017. Data and metadata available at https://www.ncdc. noaa.gov/sotc/global/201613

Osuch M, Romanowicz RJ, Lawrence D, Wong WK (2016) Trends in projections of standardized precipitation indices in a future climate in Poland. Hydrol Earth Syst Sci 20:1947-1969. https://doi.org/10. 5194/hess-20-1947-2016

Radziejewski M, Kundzewicz ZW (2000) Hydrospect-software for detecting changes in hydrological data. In: Robson A, Kundzewicz ZW (eds) Detecting trend and other changes in hydrological data, app. 2, world climate programme - applications and services. World Meteorological Organization, Geneva

Rimkus E, Kazys J, Bukantis A, Krotovas A (2011) Temporal variation of extreme precipitation events in Lithuania. Oceanologia 53(1-TI): 259-277

Skowera B, Kopcińska J, Kopeć B (2014) Changes in thermal and precipitation conditions in Poland in 1971-2010. Ann Wars Univ Life Sci- SGGW Land Reclam 46(2):153-162

Światek M (2011) Precipitation changes on the Polish coast of the Baltic Sea (1954-2003) due to changes in intensity of westerlies over Europe. Clim Res 48:23-29. https://doi.org/10.3354/cr00904

Szwed M (2015) The elements of water balance in the changing climate in Poland. Adv Meteorol 149674:13. https://doi.org/10.1155/2015/ 149674

Szwed M (2017) Projections of changes of areal evapotranspiration for different land-use units in the Wielkopolska region (Poland). Theor Appl Climatol 130(1-2):291-304. https://doi.org/10.1007/s00704016-1880-0 
Szwed M, Karg G, Pińskwar I, Radziejewski M, Graczyk D, Kędziora A, Kundzewicz ZW (2010) Climate change and its effect on agriculture, water resources and human health sectors in Poland. Nat Hazards Earth Syst Sci 10:1725-1737. https://doi.org/10.5194/ nhess-10-1725-2010

Tripolskaja L, Pirogovskaja G (2013) Impact of climate variability in Lithuania and Belarus on atmospheric precipitation infiltration: lysimetric study. Zemdirbyste-Agriculture 100(4):369-376. https:// doi.org/10.13080/z-a.2013.100.047

Van der Linden P, Mitchell JFB (eds) (2009) ENSEMBLES: climate change and its impacts: summary of research and results from the ENSEMBLES project. Met Office Hadley Centre, FitzRoy Road, Exeter EX1 3PB, UK. 160pp. Data and metadata available at http:// ensembles-eu.metoffice.com/data.html

Watson RT, Zinyowera MC, Moss RH (eds) (1998) The regional impacts of climate change: an assessment of vulnerability. Cambridge University Press, Cambridge
Woś A (1996) Zarys klimatu Polski (Outline of the Polish climate). p. 301, Wydawnictwo Naukowe UAM

Wybig J (2009) The variability of daily precipitation totals in Poland (1951-2000). Geogr Pol 82(1):21-32

Zeleňáková M, Purcz P, Poórová Z, Alkhalaf I, Hlavatá H, Portela MM (2016) Monthly trends of precipitation in gauging stations in Slovakia. Procedia Eng 162:106-111

Żmudzka E (2002) O zmienności opadów atmosferycznych na obszarze Polski nizinnej w drugiej połowie XX wieku (About the variability of precipitation in lowland Poland in the second mid-twentieth century). Wiadomości IMGW 25 (46). No 4:23-38

Zolina O, Simmer K, Kapala A, Shabanov P, Becker P, Mächel H, Gulev S, Groisman P (2014) Precipitation variability and extremes in Central Europe: new view from STAMMEX results. BAMS 95: 995-1002. https://doi.org/10.1175/BAMS-D-12-00134.1 